G. I. Nemirova, T. I. Savelyeva

\title{
Significance assessment of the risk management system to improve the quality of customs service provision
}

\section{KEYWORDS \\ risk management system; \\ correlation-regression analysis; \\ customs service; \\ performance indicators of the \\ customs service; \\ customs declaration

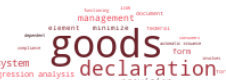 \\ risk profile $e^{\text {and }}$ \\ customs Servilce
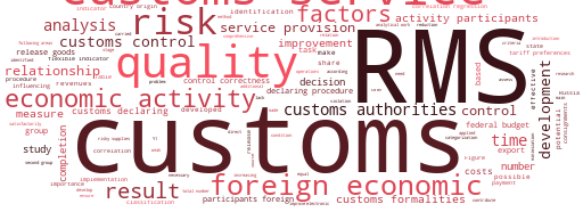

Word Cloud Generated by:

https://wordscloud.pythonanywhere.com/

\section{ABSTRACT}

In the context of limited resources of customs authorities and international trade growth, the compliance with customs legislation by participants in foreign economic activity, the quality improvement of customs service provision, the provision of completeness of the income flow to the federal budget, along with the reduction of time required for the completion of customs formalities, are important tasks. In order to solve these problems, the customs authorities use a risk management system.

The purpose of the article is to confirm the importance of the risk management system for the quality improvement of customs service provision.

The methods of system analysis, questionnaires, as well as the project method, the method of correlation-regression analysis, the statistical-probabilistic method, modeling, and the process approach were used herein in order to develop directions for improving the risk management system, substantiate the proposals and recommendations.

The results of the study using the method of correlation-regression analysis made it possible to identify the relationship between improving the risk management system and improving the quality of providing the customs service "customs declaring procedure". A direct strong relationship between the quality of customs services and the number of automatically issued electronic declarations filed by low-risk foreign trade operators, as well as a direct strong relationship between the quality of customs services and the number of automatic risk profiles, was established based on the R-squared value "1.00". The R-squared values "0.90" and "0.99" confirm the existence of a direct relationship between the time limit for customs operations when goods are placed under the customs procedure for export and import, respectively, and the quality of customs service provision. The results of the revealed dependence serve as a starting point for the development of practical recommendations for the quality improvement of the formation and application of risk profiles in the field of customs value control, as well as the improvement of the procedure of formation and application of risk profiles in the field of export control, and the development of a methodology for assessing the effectiveness of the risk management system.

Nemirova, G. I., \& Savelyeva, T. I. (2020). Significance assessment of the risk management system to improve the quality of customs service provision. Economic consultant, 31 (3), 42-52. doi: 10.46224/ ecoc. 2020.3 .3 


\section{INTRODUCTION}

C urrently, the risk management system (RMS) is applied in the customs authorities of the Russian Federation at all the main stages of customs control: upon arrival, customs transit, declaration, etc. All control activities of the customs authorities: the control over compliance with prohibitions and restrictions; the correctness of the classification by the commodity nomenclature of the foreign economic activity of the Eurasian Economic Union; the compliance with intellectual property rights; the control of the country of origin and the legality of tariff preferences application, etc. are based on the RMS.

The RMS is a set of interconnected bodies and management tools that provide analysis, identification, assessment, and minimization of risks during customs control [1]. According to the practice of customs authorities, the RMS is a source of further development of the technology for the automatic issuance of a declaration for goods, a tool for minimizing the information costs for service consumers and increasing the effectiveness of the implementation of forms of customs control.

The development of the RMS potential leads to an improvement in the customs declaration quality by minimizing the information costs and is currently relevant. Previously, risk management occupied only the fifth place in terms of the importance of areas for customs service improvement trailing the regulatory and information technology support of the customs authorities, analysis of foreign economic activity, partnership relations between the customs authorities and business [2].

As a result of the application of the RMS by the customs authorities in 2019, additional 32.1 billion rubles were collected, 48,246 cases of administrative violation and 543 criminal cases were initiated, 29,084 adverse decisions on the release of goods and 17,668 decisions on the prohibition against the import/export of goods were made [3].

The importance of research on the RMS in the customs service provision is supported by the availability of publications in this area. Various quality aspects of the customs service provision in conjunction with the RMS presented in the studies by Makrusev [2], Anisimov [18], Popov [13], Meshechkina [6], Agamagomedova [19], and Saurenko [1] develop the ideas about customs risk and the functioning of the RMS.

The abovementioned scientists have made a significant contribution to the development of theoretical provisions on the role of the RMS in the process of customs service provision. However, inadequate attention has been paid to the potential of the RMS in terms of the reduction of the time for completion of customs formalities and a decrease in the nonproduction costs of foreign economic activity participants - quality assessment of the RMS on the part of foreign economic activity participants.

The objective of this article is to assess the significance of the RMS in order to improve the "customs declaration" service both for the state and for the participants in foreign economic activity. 


\section{MATERIALS AND METHODS}

The methodology of this study involves the determination of the relationship between the factors characterizing risk management activities and the factors characterizing the work of the Federal Customs Service of Russia as a whole.

The methodological basis of the study involves the correlation and regression analysis carried out using the Microsoft Excel spreadsheet editor. The construction of a correlation matrix between dependent and independent values is the basic method for assessing the relationship between the phenomena under study.

Regression analysis and correlation analysis are statistical research methods that establish the dependence of a particular parameter on one or more independent variables. The purpose of the regression analysis is to determine the degree of the determinism of the variation of the dependent variable by the independent variables.

The main task of correlation analysis in this study is to determine the factorial and effective attributes of the problem under study.

Information on the results of the functioning of the RMS is represented as independent variables, while the information on the satisfaction of the participants in foreign economic activity, the reduction of the time for completion of customs formalities during the release of goods, as well as the flow of income administered by the customs authorities to the federal budget, are dependent variables.

The initial data for the correlation and regression analysis were the reports on the customs statistics of the Federal Customs Service of Russia published on the official website, including information on the implementation of control activities and the RMS.

\section{RESULTS}

The factors affecting the quality of customs service provision from the point of view of its consumers, namely: the participants in foreign economic activity $(\mathrm{Y} 1)$ and the state (Y2), are divided into 2 groups in connection with the establishment of different degrees of influence based on the analysis results. The results of the analysis of the first group of factors (Table 1) showed the following:

Table 1

Dynamics of the factors that have a significant impact on the quality of customs services (1 st group of factors) [4].

\begin{tabular}{|c|c|c|c|c|c|c|c|c|}
\hline Period & Y1 & Y2 & X1 & X2 & X3 & X4 & X5 & X6 \\
\hline 2018 & 85.00 & 102.12 & 46.90 & 26.60 & 43.70 & 82.30 & 0.41 & 1.21 \\
\hline 2017 & 83.00 & 102.80 & 28.20 & 7.30 & 42.50 & 80.30 & 0.76 & 1.51 \\
\hline 2016 & 82.00 & 101.10 & - & - & - & - & 0.79 & 1.61 \\
\hline 2015 & 81.00 & 101.10 & - & - & - & - & 0.85 & 1.73 \\
\hline
\end{tabular}




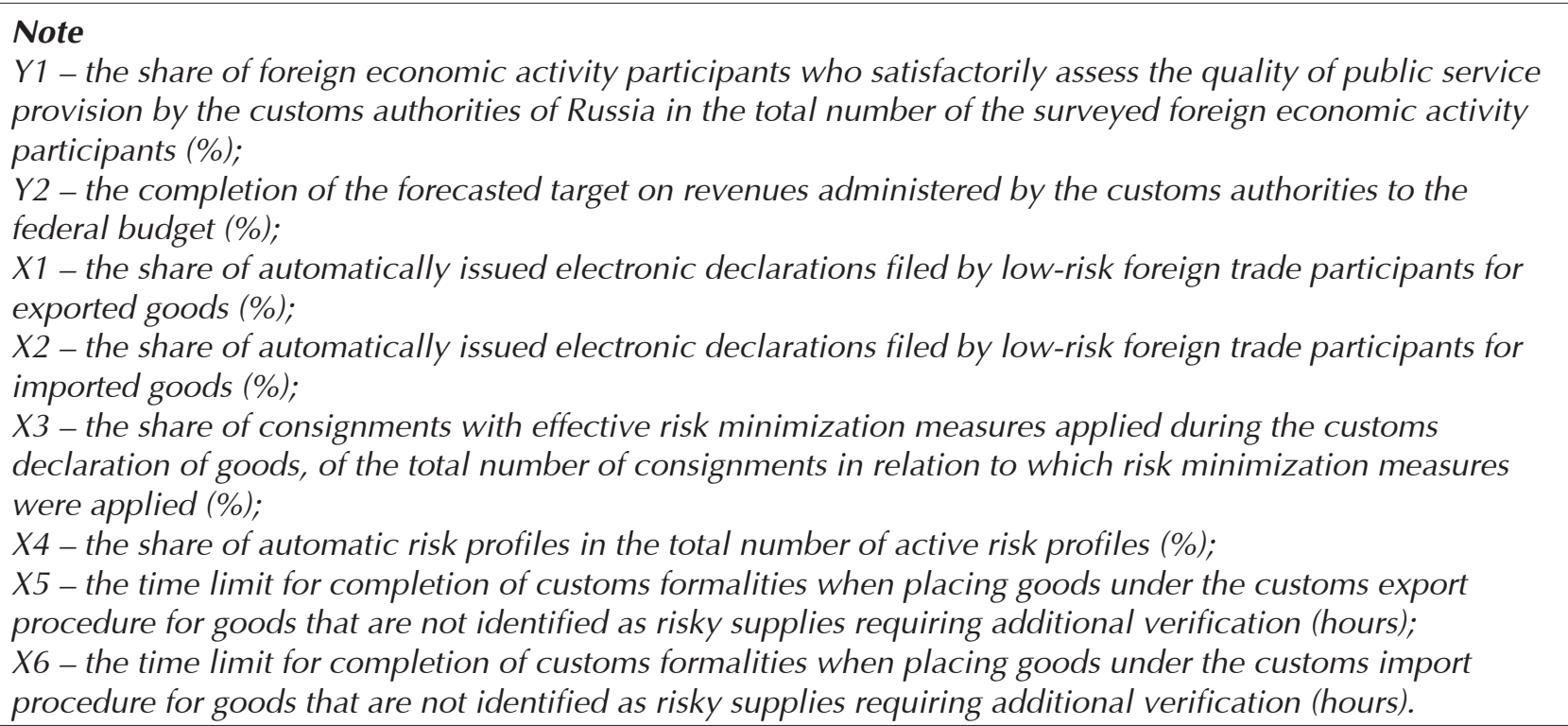

Based on the results of the analysis, a direct strong relationship was revealed between the number of foreign economic activity participants who satisfactorily assess the quality of public service provision by the customs authorities of Russia in the total number of interviewed participants and:

- the time limit for completion of customs formalities when placing goods under the customs export procedure for goods that are not identified as risky supplies requiring additional verification by $90 \%$ (Figure 1);

- the time limit for completion of customs formalities when placing goods under the customs import procedure for goods that are not identified as risky supplies requiring additional verification by $99 \%$;

- the share of automatically issued electronic declarations filed by low-risk foreign economic activity participants for exported and imported goods by $100 \%$;

- the share of automatic risk profiles in the total number of active risk profiles by $100 \%$.

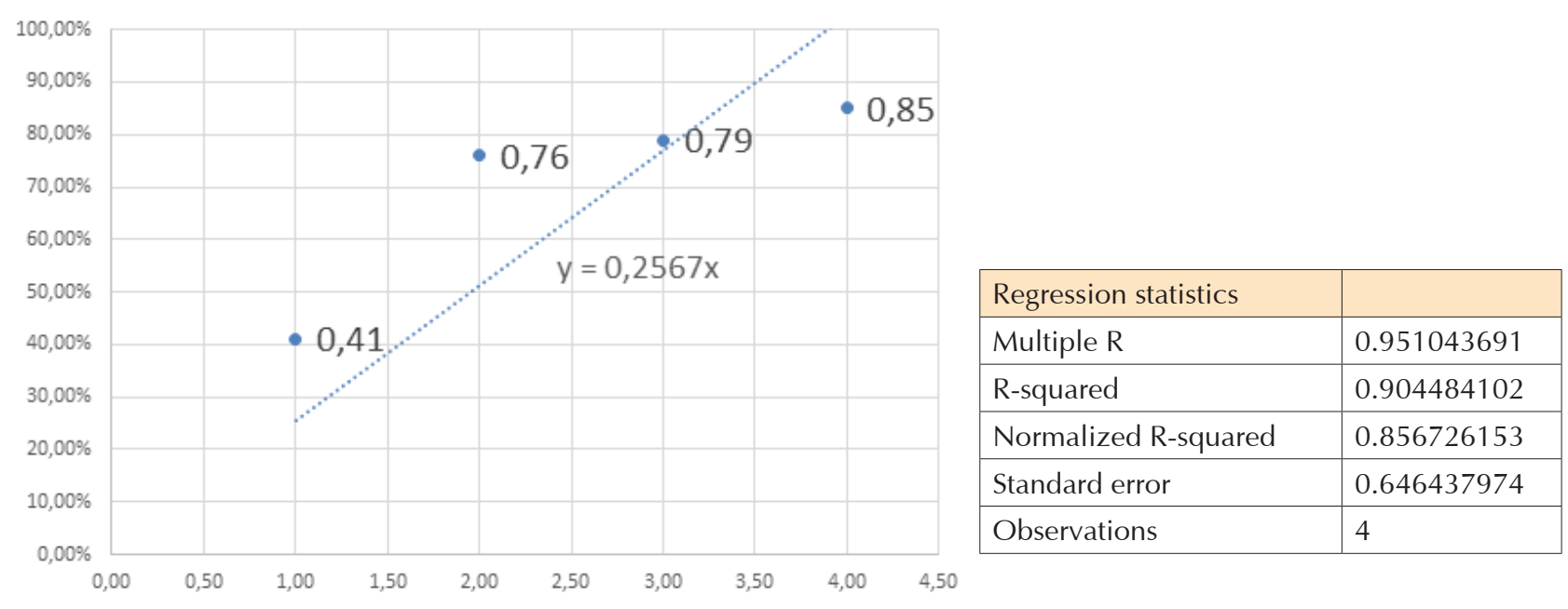

Figure 1 Correlation of the number of foreign economic activity participants who satisfactorily assess the quality of customs services and the time of issue of the export declarations for goods 
For the purposes of the facilitation of the foreign economic activity, the customs authorities have developed a Comprehensive Program for the Development of the Federal Customs Service until 2020, the implementation of which is based on the maximum automation of the customs formalities [5]. The program provides for acceleration of the completion of customs formalities by reducing the number of documents, introducing automatic registration of declarations for goods in the form of an electronic document.

The foreseen problem solving contributes to the provision of favorable conditions for participants in foreign trade, which is confirmed by the results of the study by the World Bank, according to which Russia ranked 31st among 190 countries participating in the study in terms of Ease of Doing Business [6].

The priority of electronic declaration of goods and interaction of state bodies with participants in foreign economic activity, provided for in the EAEU Customs Code, is aimed at simplifying customs formalities and accelerating their implementation, which ultimately should contribute to the development of foreign economic activity [7].

The potential advantage of the RMS involves the possibility of development in the system of artificial intelligence, capable of transforming the data set from known and unknown risk factors to ensure accurate identification of the risks [8].

The RMS is characterized by its adaptability and ability to innovate. The RMS is the basis for the development of technology for automatic issuance and automatic registration of declarations for goods [9]. Automatic decision making significantly reduces the burden on customs officials, allowing them to focus their efforts on the riskiest deliveries [10].

Automatic release is used only for faithful foreign economic activity participants, low-risk companies from the so-called "green sector" [11].

The results of the dependence of the factors of the first group indicated the ability of the RMS to affect positively the further development of the technology for the automatic issuance of the declarations for goods, which is a source of improvement of the efficiency of customs operations, as one of the quality criteria for the customs service provision.

The results of the analysis also confirmed the presence of a direct relationship between the number of effective risk profiles and the level of federal budget revenues from customs payments, which indicated the potential of the RMS in terms of quality improvement of the performance of customs services. In accordance with the result obtained, the relationship between the completion of the forecasted task on incomes to the federal budget administered by the customs authorities and the share of consignments with effective measures to minimize risks applied during the customs declaration of goods on the total number of consignments in respect of which the measures on risks minimization were applied was equal to $100 \%$.

The timeliness and completeness of the administration of customs revenues are of great importance in the construction of an effective system for ensuring the economic security of the Russian Federation. The revenues administered by the customs authorities are among the sources of replenishing the federal budget [12]. 
The factors, influencing the value of federal budget revenues from customs payments, were also studied by Popov using the correlation-regression analysis. The researcher established the relationship between the amounts of customs payments and the number of customs officials, the structure of exports and imports [13].

For a more detailed study of the relationship between the individual elements of the RMS and the quality of customs services, the information on the influencing factors of the second group was analyzed (Table 2 ).

Table 2

Dynamics of factors affecting the quality of customs services (2nd group of factors) [14].

\begin{tabular}{|c|c|c|c|c|c|}
\hline Period & Y1 & Y2 & X1 & X2 & X3 \\
\hline Q3 2019 & 49.00 & 71.65 & 2728 & 49.36 & 54.20 \\
\hline Q2 2019 & 46.00 & 45.84 & 2200 & 48.90 & 53.50 \\
\hline Q1 2019 & 39.00 & 21.99 & 2262 & 46.50 & 52.70 \\
\hline Q4 2018 & 43.00 & 102.10 & 2610 & 51.90 & 51.40 \\
\hline Q3 2018 & 43.00 & 78.80 & 2381 & 85.30 & 52.00 \\
\hline Q2 2018 & 41.00 & 54.60 & 2582 & 85.80 & 53.90 \\
\hline Q1 2018 & 36.00 & 24.80 & 549 & 85.40 & 55.80 \\
\hline
\end{tabular}

\section{Note}

Y1 - Reduction of the time required for completion of customs formalities when releasing goods placed under the customs procedure for export, not subject to additional types of state control and which are not identified as risky supplies requiring additional verification (hours);

Y2 - The level of completion of the projected target on incomes to the federal budget administered by the customs authorities (\%);

$X 1$ - The number of risk profiles developed in the following areas: control over the correctness of classification of goods, control over the correctness of determination of the country of origin of goods; control over the provision of tariff preferences (pcs.);

$X 2$ - The share of consignments, in respect of which, during customs control using the risk management system during their customs declaration, violations of customs legislation were detected, of the total number of consignments in respect of which customs control was carried out using the risk management system during their customs declaration (\%);

X3 - The share of consignments subjected to customs inspection, as a result of which violations of customs legislation were revealed or as a result of which the release of goods was refused, in the total volume of inspected consignments of goods (in percentage) (\%).

The analysis of the second group of factors was also carried out in order to establish the factors influencing the quality of customs service provision with regard to the state and foreign economic activity participants.

The results of this analysis showed a moderate dependence of 50\% between the reduction in the time of completion of the customs formalities when releasing the goods placed under the export customs procedure and the number of developed risk profiles in the following areas: control over the correctness of goods classification, control over the correctness of determination of the goods country of origin, control over the provision of tariff preferences.

In other cases, a weak relationship was found between the factors. For example, the relationship between the level of completion of the predicted task for the revenues administered 
by the customs authorities to the federal budget and the number of developed risk profiles in the following areas: control over the correctness of goods classification, control over the correctness of determining the goods country of origin, control over the provision of tariff preferences, is equal to $37 \%$, while the relationship between the share of consignments for which customs control was carried out using the RMS for their customs declaration and the number of developed risk profiles in the following areas: control over the correctness of goods classification, control of the correctness of determining the goods country of origin, control over the provision of tariff preferences is equal to $18 \%$.

The authors believe that the establishment of a weak relationship between the influencing factors of the second group is due to the lack of information necessary for a detailed analysis.

The comprehensive analysis is hampered by the lack of similar information on "value" risk profiles, the speed of customs operations within the framework of the customs procedure for release for domestic consumption, and the time for making decisions on measures to minimize the risk profile, other than customs inspection. The lack of full information about these factors confirms the need to develop a methodology for assessing the effectiveness of the RMS based on the assessment of the RMS for each quality criterion for customs service provision.

\section{DISCUSSION}

The results of the correlation and regression analysis made it possible to identify the elements of the RMS, the development of which is aimed at quality improvement of customs service provision for all consumers of customs services (Figure 2). The elements of the RMS that increase the quality of the customs declaring procedure are: automatic risk profiles, flexible indicators of risk profiles in the direction of customs value control, interdepartmental risk profiles, analytical work performance, comprehensive assessment of the RMS, shifting the focus of the customs control to the post-release stage, risk categorization.

The identification of automatic risk profiles with mandatory minimization measures makes it possible to neutralize the time costs for decision making on the application or nonapplication of one or another form of customs control and measures that ensure customs control, since it is a clear algorithm for any official involved in the release of goods. As a result, the terms for the release of goods are reduced due to the absence of the need to spend time interpreting the description of the measures and holding consultations with the structural units of the customs authority.

The identification of risk profiles in the field of customs value control with a flexible indicator leads to a similar effect of time saving for the release of goods. The flexible indicator of the level of customs value eliminates the time costs associated with the calculation of the amount of security for the payment of customs duties and taxes, as well as the formation of a request for submission of additional documents in cases where the value of the declared customs value is 
not subject to adjustment, when the time spent on additional verification terminates with the acceptance of the customs value.

The use of interdepartmental risk profiles increases the efficiency and promptitude of the customs declaring procedure, as it eliminates the need to interpret the description for measures to minimize the risk profile and consult with the structural units of the customs authorities when special knowledge or additional information about a permit document is required. The organization of interaction between the customs authorities and government authorities, the functions of which include the conduct of export control, would make it possible to clearly distinguish between risky and non-risky supplies [15].

The mainstreaming of the analytical work on the collection and analysis of the information necessary to develop a risk profile leads to an improvement in the quality of the formation of a risk profile in terms of identifying a risk profile exclusively in relation to a risky delivery, which is also aimed at the compliance of customs declaration with quality criteria.

The development of a system of indicators for RMS quality assessment, grouped according to the quality criteria for customs service provision, will make it possible to improve the risk management process through feedback channels. To date, there is no such system of indicators in relation to the quality of customs service provision in general. The presence of actually one indicator for the quality assessment of customs services, "the share of foreign economic activity participants satisfactorily evaluating the services", in such a generalized form is clearly insufficient to form an idea of the level of individual services provided, the problems of their provision and obtaining the information to justify the managerial decisions. These goals require a system of assessment indicators with respect to the interests of various stakeholders that contributes to the formation of directions for improvement of customs services management [16].

The formation of risk profiles with a mandatory measure to minimize the risk of "postrelease control" implies a shift in the emphasis of customs control to the stage after the release of goods. This element of the RMS makes it possible to increase the efficiency and efficiency of customs declaration in cases when it is impossible to create an effective risk profile based on the results of the analytical work done and it is impossible to make a final decision within the risk profile that minimizes the risk of violation of the law.

The RMS includes the risk categorization of foreign economic activity participants - the distribution of foreign economic activity participants into groups depending on the assessment of the likelihood of a violation of the law by a specific person (low, medium, and high risk levels), obtained by analyzing information about foreign economic activity participants and the results of customs operations with goods transported by them [17]. Risk categorization is aimed at increasing the efficiency of the customs declaring procedure by not applying the forms of customs control, or measures to ensure customs control of consignments declared by the participants in foreign economic activity of a low level of risk.

Further development of the above elements of the RMS will lead to an increase in the efficiency and promptitude of the customs service provision. 


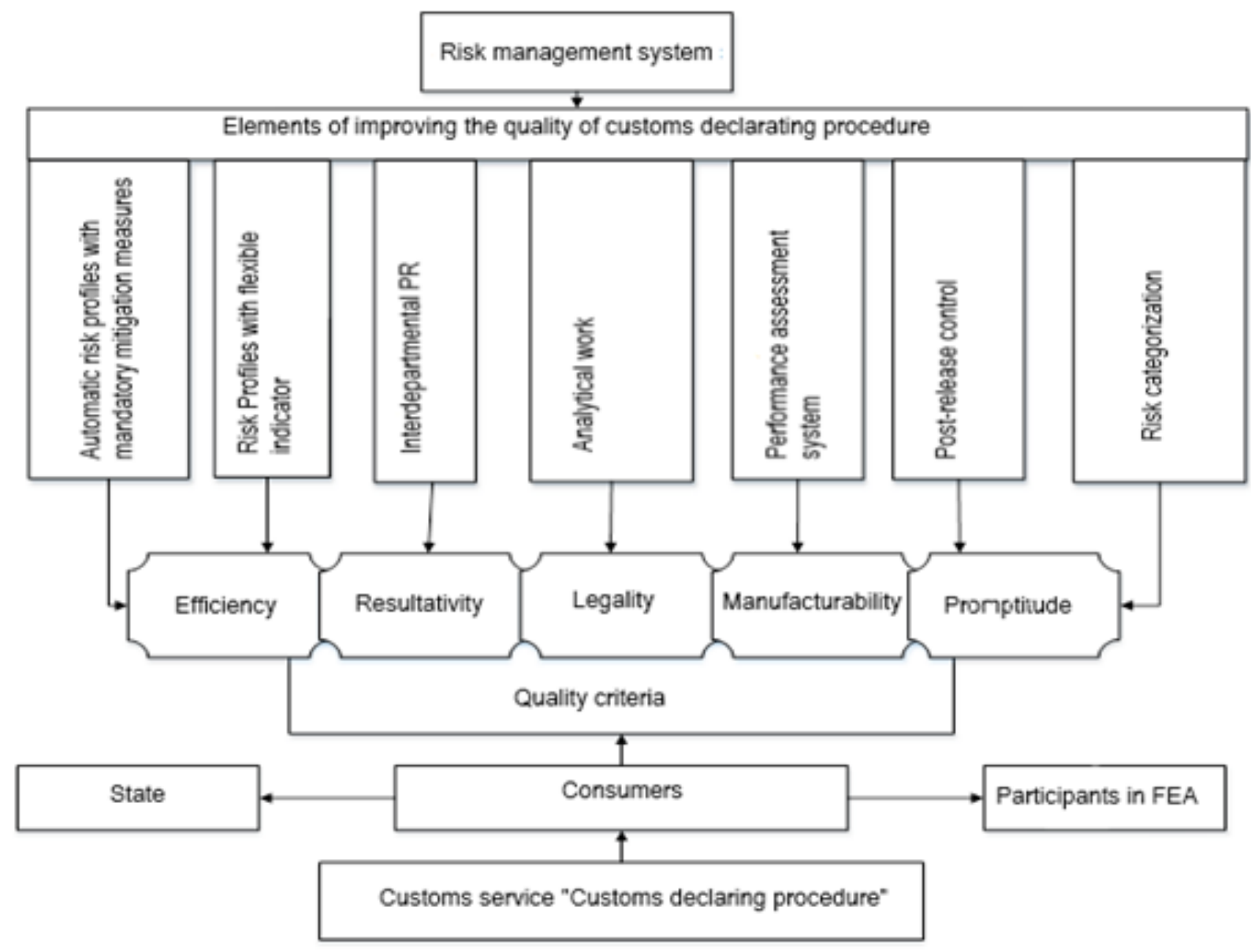

Figure 2 Significance of the risk management system for the quality improvement of the customs service "Customs declaring procedure"

The current practice of using the RMS shows that the system of risk profiles is the weak link [18]. The main condition for customs control automation is the possibility of formalizing the grounds for customs formalities and the introduction of the appropriate parameters into the software [19].

The paramount tasks of the Federal Customs Service are to improve the customs declaring procedures aimed at creating favorable conditions for the acceleration of goods turnover across the border of the Eurasian Economic Union, reduce the time of customs declaring, and increase the efficiency of customs control. The achievement of these tasks is facilitated by the introduction and functioning of the RMS [20].

\section{CONCLUSION}

Thus, the conducted research confirms the importance of the RMS in the provision of customs services, especially the "customs declaring procedure" service. The potential of the RMS should be developed in the field of increasing the RMS automation, the development of exclusively automatic risk profiles with flexible indicators, the identification of which means a 
direct instruction to a specific action for the official who identified it, bypassing the information costs of searching and analyzing the information necessary for decision making. "Maximum results at minimum costs" is the task of further improvement of the RMS aimed at quality improvement of customs services.

\section{REFERENCES}

1. Anisimov, V.G., Anisimov, E.G., Arslanov, R.F., Bogoev, E.M., Goloskokov, V.I., Lipatova, N.G., Popov, V.V., Saurenko, T.N., \& Tebekin, A.V. (2015). Economic and Customs Risk Management: Monograph. Moscow: RIO of the Russian Customs Academy. (p. 180).

2. Makrusev, V.V. (2008). State Customs Services. Moscow: Publishing House RTA. (p. 195).

3. Federal Customs Service. (2020). Final Report on the Results and Main Areas of Activity of the FCS of Russia in 2019. URL: http://customs.ru/activity/results/itogovye-doklady-orezul-tatax-deyatel-nosti/document/229693

4. Federal Customs Service. (2019). Final Report on the Results and Main Directions of the FCS of Russia in 2018. Retrieved May 6, 2020, from http:/customs.ru/activity/results/ itogovye-doklady-o-rezul-tatax-deyatel-nosti/document/175571

5. Vladimir Bulavin: The FCS of Russia Advocates the Creation of a Conflict-Free Business Environment. (2018). Retrieved May 6, 2020, from http://www.customs. ru/index.php?option $=$ com_content $\&$ view $=$ article $\& i d=26261: 2018-02-08-07-10$ 31 \&catid=40:2011-01-24-15-02-45\&Itemid= 2094 \& Itemid = 1835

6. Meshechkina, R.P. (2019). Quality Improvement of Customs Control When Declaring Goods. Bulletin of Belgorod University of Cooperation, Economics and Law, 4, 100-111.

7. The Main Directions of Budgetary, Tax and Customs-Tariff Policy for 2019 and for the Planning Period of 2020 and 2021. (2019). Approved by the Ministry of Finance of Russia. Retrieved May 6, 2020, from http://www.consultant.ru/document/cons_doc_ LAW_308390/

8. Satyadini, A.E., Basir, A., \& Barata, A. (2020). A Cutting-Edge Approach to Risk Management Framework: Upswing Customs Administration. Journal of Management Research, 12, 57-73.

9. Savelyeva, T.I. (2018). Analysis of the State of the Risk Management System in the Mechanism of Improving the Quality of Customs Services. Financial Economics, 7, 1357-1362.

10. Order of the FCS of Russia No. 1312 "On the Decision of the Board of the FCS of Russia of May 26, 2016 "On the Results of the Application of Technologies for Automatic Registration of Declarations for Goods and Automatic Release of Goods, the Prospects for Their Development". (2016, July 1).

11. Alekhina, O.V., Ignatieva, G.V., Smirnova, I.A., \& Tarasova, N.L. (2018). Digital Technologies in Customs. Bulletin of the SGSEU, 3 (72), 9-15. 
12. Nemirova, G.I., \& Novikov, S.V. (2018). Customs Control after the Release of Goods as a Tool for Ensuring Economic Security: Monograph. Moscow: RUSAYN. (p. 182).

13. Popov, V.V. (2017). Economic and Statistical Analysis of the Impact of Indicators of the Activities of Customs Authorities on the Volume of Customs Payments. Economic Analysis: Theory and Practice, 16 (11), 2189- 2202.

14. Federal Customs Service. (n.d.). Implementation Details. Control Activity. Performance and Efficiency Assessment System. Retrieved March 15, 2020, from http://customs.ru/ activity/kontrol-naya-deyatel-nost-/rating/svedeniya-o-realizaczii

15. Savelieva, T.I., \& Nemirova, G.I. (2018). Priorities of the Risk Management System in the Context of the Development of the Single Window Mechanism. In Digital Customs and the Single Window: Trends and Content. Collection of Materials of the II Scientific and Practical Conference on April 24, 2018 (pp. 6-12). State Public Educational Institution of Higher Education "Russian Customs Academy.

16. Gupanova, Y.E., Nemirova, G.I., \& Suglobov, A.E. (2018). The Analysis of Customs Services Practice in the Conditions of the Eurasian Economic Union: Problems and Directions of Improvement. Journal of Advanced Research in Law and Economics, 9 (4(34)), 1259-1266.

17. Nemirova, G.I., \& Savelyeva, T.I. (2018). Theoretical Foundations of the Formation of a Risk Management System in the Field of Customs Services. Customs, 3, 25-28.

18. Anisimov, V.G., Anisimov, E.G., Rodionova, E.S., \& Saurenko, T.N. (2016). Stochastic Model for Assessing the Efficiency of Customs Risk Management. Management Consulting, 9 (93), 83-94.

19. Agamagomedova, S.A. (2019). Automation of Customs Control: Conditions and Administrative and Procedural Support. Vestnik of Lobachevsky University of Nizhni Novgorod, 14, 81-86.

20. Nagornaya, M.S., \& Yakimenko, E.S. (2019). Risk Management System as an Effective Mechanism for the FCS of Russia in the Context of Modernization. Management in Modern Systems, 2 (22), 14-18.

\section{INFORMATION ABOUT THE AUTHORS}

1. Gulzida I. Nemirova (Russia, Moscow region, Lyubertsy) - Doctor of Economics, Associate Professor, Professor of the Department of Customs Operations and Customs Control. Russian Customs Academy. E-mail: nemirova@bk.ru

2. Tatiana I. Savelyeva (Russia, Moscow region, Lyubertsy) - Applicant for the degree of candidate of economic sciences. Department of Customs Operations and Customs Control. Russian Customs Academy. E-mail: boney_tan@mail.ru 